\title{
Analysis on Applied Undergraduate Teaching Staff Construction
}

\author{
Yan Hou \\ Qilu Normal University, Jinan, Shandong, 250014, China. \\ 122365871@qq.com
}

\begin{abstract}
With the development of social economy, the demand for applied talents with both theoretical foundation and practical ability is increasing day by day. To cultivate applied undergraduate talents suitable for the needs of modern society, there must be a teaching staff with reasonable structure, theoretical research and time ability. In consideration of this, this study elaborates on the necessity of teacher construction in applied universities, combines with its development status, and proposes a feasible strategy for the construction of applied teaching staff.
\end{abstract}

Keywords: Applied undergraduate, teaching staff, construction.

\section{Introduction}

In order to adapt to China's economic restructuring and meet the popularization of higher education, applied undergraduate colleges have formed their own characteristics and idea of running a school after more than ten years of development. The goal is to cultivate application-oriented talents with strong practical ability and strong professional ability, while the construction of the teaching staff is an important guarantee for achieving this goal. In the new development period, it is undoubtedly of practical significance and strategic significance to analyze the construction of the teaching staff of undergraduate colleges.

\section{The Necessity of Teaching Staff Construction in Applied Universities}

\subsection{The Demand for Talents in the New Era Forces to Reform Teaching Staff Construction Under the New Normal of Economic Development}

The transformation and upgrading of the economic structure continues to advance, China faces the double squeeze of high-end advanced technology in developed countries and labor-intensive and lowcost competition in developing countries, and the current structural contradiction between the general surplus of the general skilled labor force and the serious shortage of high-quality applied talents is prominent day by day. The supply of higher education talents and the demand of the labor market are misplaced. It is urgent for higher education institutions to train application-oriented, compound and innovative talents lacked in the first-line production and service seriously. And the change in the demand for talents has put forward corresponding requirements for the construction of the current teaching staff of colleges and universities, and it is urgent to carry out the reform of the construction of teaching staff.

\subsection{National Major Strategy and Policy Implementation Require the Reform of the Teaching Staff Construction}

In the new era, our country proposes innovation-driven development, China manufacturing 2025, Internet +, mass innovation, mass entrepreneurship, "the Belt and Road" and other national major strategies and a series of policy documents issued by local education departments on the transformation of local general undergraduate institutions provide strong policy support and rare development opportunities for local general undergraduate colleges to achieve application-oriented transformation and reform, and also put forward higher requirements for the construction of the application-oriented teaching staff. Only by building a high-level application-oriented teaching staff can we cultivate high-level applied talents and serve the national and local economic development. 


\subsection{The Orientation of Applying Undergraduate Colleges and Universities Requires the Transformation of Teaching Staff}

Applied undergraduate colleges need to strengthen the construction of applied teaching staff, which is determined by the inherent characteristics of the University of Applied Technology. The University of Applied Technology is a type of education that is parallel to ordinary universities and is oriented to professional education and oriented to work and life which is responsible for cultivating high-level technical application talents, conducting applied scientific research and technological innovation, serving employment and regional development, and promoting lifelong learning. Whether the University of Applied Technology can cultivate high-level technical application talents with innovative spirit and practical ability depends on the teachers, and teachers are the main force and lifeline of college construction and development. Teachers are required to have the ability to be competent in professional theoretical teaching, but also to have the ability to guide professional practice. Whether the deep transformation of the colleges can succeed depends on the transformation of the teaching staff to a large extent. The construction of applied teaching staff will directly affect the cultivation of high-level applied talents in local general undergraduate colleges.

\section{The Status Quo of Applied Undergraduate Teaching Staff}

With the continuous expansion of the scale of applied undergraduate colleges and the rapid increase in the number of disciplines, there is a certain gap between the number of teaching staff members, personnel structure, teaching and research level, and the school-running orientation and talent training objectives of applied undergraduates.

\subsection{It Is Difficult to Introduce High-Level Talents}

Some applied undergraduate colleges are affected by factors such as geography, policy, financial resources, support platform and industry reputation. There are certain difficulties in the introduction of high-level talents, resulting in the inability to form a high-level innovation team of production, education and research.

\subsection{The Structure of The Teaching Staff Is Unreasonable}

On the one hand, the age structure of the teaching staff is unreasonable. The increase in new majors has led to an increase in the number of new teachers introduced, resulting in a large number of young teachers, and an imbalance in the proportion of the old, middle and young levels; On the other hand, the structure of the title of the teaching staff is unreasonable. There are many young teachers, and the title evaluation system is the same as that of ordinary higher education institutions, which causes a serious shortage of teachers with high professional titles.

\subsection{The Management Mechanism of Teaching Staff Is Seriously Lagging Behind}

Under the influence of economic management mode, teacher management principles and talent evaluation system, the enthusiasm of teachers is not fully mobilized, which restricts the comprehensive and deep construction of the teaching staff.

\subsection{Teacher's Training Mechanism Is Not Perfect}

Most of the applied undergraduate colleges have done a good job in improving the level of teachers' qualifications, while the skills training mechanism and implementation of teachers in school-enterprise cooperation need to be extremely strengthened.

\subsection{The Teacher's "Applicability" Quality Is Not Outstanding Enough}

The teachers of applied undergraduate colleges have the professional ethics and theoretical level of the teachers of ordinary colleges and universities. However, they cannot fully own practical applications and knowledge innovation, and there are fewer teachers with multiple versatility. 


\subsection{Lack of High-Level Talent And Innovation Teams}

Most local undergraduate colleges belong to newly-built undergraduate colleges, with a short history of development and weak overall strength. Also, the overall strength of the teaching staff is not strong enough. The overall number of leading talents, high-level academic leaders and academic backbones and the construction of echelons are insufficient, and there is a lack of high-level talents that lead the development of the industry. The existing high-level talent team is not strong in leading the industry, and has insufficient promotion effect on economic development and industry development. The recognized high-level and excellent research and innovation teams are few in number.

\subsection{The Internationalization Level of the Teaching Staff Is Low}

The current economic globalization has made human resources flow around the world, and the national "the Belt and Road" strategy puts new demands on the cultivation of international talents. To cultivate more international talents, it is necessary to continuously improve the internationalization level of the local undergraduate teaching staff. The internationalization of teaching staff is the key to the internationalization of higher education. The essence of the internationalization of teaching staff is to build a multi-national, multi-nationalized teaching team with a cross-cultural education background. At present, among the full-time teachers of most local undergraduate colleges, the proportion of teachers with overseas work and study abroad experience is relatively small, the bilingual teaching ability is low, and the level of internationalization is relatively low, which cannot meet the needs of cultivating internationalized talents.

\section{Countermeasures for the Construction of Teaching Staff in Applied Undergraduate Colleges}

China's higher education is facing a period of development and upgrading of golden opportunities. It also provides good policy support and rare opportunities for the development of applied undergraduate colleges and the construction of high-level teachers.

\subsection{Innovatively Implement High-Level Talent Introduction Training Mechanism}

It is necessary to adopt the principle of "introducing on demand, highlighting key points, and stressing practical results". Focusing on discipline construction, and focusing on the applicationoriented undergraduate school-running goals, vigorously unblocking channels, and through the construction of relevant systems such as preferential policies and relaxed environment, vigorously introducing high-level talents at all levels. Paying attention to the training of young teachers' academic level and practical skills, and improving the academic level of young teachers through schoolenterprise cooperation, selection of visiting scholars, and participation in skill competitions.

\subsection{Vigorously Implementing the Growth of Young Teachers and the Leader of the Discipline Plan}

Further improving the implementation of the Youth Teachers to pass on experience, and effectively promoting the growth of young teachers in terms of roles change, teaching skills, education level and innovation ability. According to the layout and planning of the discipline, paying attention to the cultivation and selection of academic leaders. Truly exerting the key role of academic leaders in the construction of teaching staff in applied undergraduate colleges, and gradually establishing a branch team to promote the healthy and sustainable development of the teaching staff.

\subsection{Actively Building A Learning and Inclusive Teaching Staff}

No matter how many measures are taken to build the teaching staff, learning is a must. Working hard to learn modern technology theory and expertise; Learning new teaching content, methods and 
means which reflect times requirement; Learning modern management concepts, methods and practices. The teaching staff should be transformed into a system combining openness with mobility. Not only should we have a relatively stable in-service teaching staff, but also the construction of parttime teaching staff through foreign and off-campus recruitment should be strengthened, so that the entire teaching staff is inclusive.

\subsection{With "Foreign Language +" as the Starting Point, It Is Necessary to Promote the Internationalization of Teaching Staff Through Multiple Channels}

The national "the Belt and Road" strategy puts forward new demands for the cultivation of international talents. It is necessary to continuously improve the internationalization level of teaching staff and strengthen the construction of "bilingual" professional teachers. Local undergraduate colleges should incorporate "foreign language + " into the central position of teaching staff strength training, conduct various language training for full-time teachers, and comprehensively improve teachers' foreign language ability; Vigorously introducing outstanding talents with overseas study background or multinational company work experience, and openly recruiting professors and associate professors overseas, and hiring foreign experts to serve as full-time or part-time teachers, and gathering a group of outstanding leaders with international competitiveness; Establishing friendly and cooperative relations with foreign high-level applied technology universities, and actively striving for various types training programs to go abroad for each kind of teachers, and supporting teachers to use inter-school exchanges to study abroad, selecting academic leaders, academic backbones, young and middle-aged backbone teachers to study abroad to comprehensively improve the internationalization level of the teaching staff.

\subsection{Deepening the Management System of the Teaching Staff Construction}

Taking the management system deepening construction as an opportunity, and it should be defined that in addition to teaching and researching capabilities, teachers of applied undergraduate colleges should also have higher levels in terms of technical application ability and applied talent training ability. The principle of on duty as required and competitive recruitment should be implemented in order that the personnel and affairs can be managed effectively.

\subsection{Strengthening the Quality Construction Work of Teachers' "Double Teachers"}

The teacher's "double teacher" quality means that the teacher should not only have the industry's theoretical knowledge and practical ability, but also should have the ability of integrating the industry's professional knowledge and practical ability into the education and teaching process. Applied undergraduate colleges should establish an effective platform for teachers' practical ability and innovative ability through school-enterprise cooperation and promotion of scientific research.

\section{Summary}

The applied undergraduate teaching staff must adhere to the scientific development concept and establish an advanced teaching staff construction concept, establish the concept that "teaching resources are the first resources of the school" and establish a "people-oriented" concept of scientific talents, and respect knowledge, value talents, care for talents, and establish the concept that "everyone can be talented". Paying attention to both ability and political integrity, and not only looking at academic qualifications, and professional titles, and not to stick to one pattern to select talents, in order to realize "undertaking retains talents, environment retains talents, feeling retains talents, and treatment retains talents". Working hard in the construction of hardware and software environment. And establishing a "people-oriented" thinking, and strengthening the construction of campus culture, and increasing emotional investment, and striving for creating a good atmosphere of " The great birds find a well wood to rest and well-knowledge people will work for the one who knows the treasure. " so as to adapt to the requirements of applied undergraduate teaching staff. 


\section{References}

[1]. Anonymous, Applied undergraduate teaching staff construction study, thesis website.

[2]. Wang Lily, Pei Henan, Applied undergraduate college teaching staff construction analysis, Youth Times, 2015[7].

[3]. Zhang Yean, Wang Xing, Han Yao, Applied teaching staff construction: Key path for local undergraduate colleges to transform, Consumption Guide, 2016[7].

[4]. Anonymous, Applied undergraduate talent cultivation and teaching staff construction study, Duding. Com.

[5]. Anonymous. Applied undergraduate colleges teaching staff construction analysis. TOP Journal. Com. 